\title{
Relation of Handwashing and Isolate of Bacteria from Mobile Phones of Healthcare Workers in a University Hospital
}

\author{
Min-Gyu Choi ${ }^{1, *}$, Sang-Ha Kim,, ${ }^{2, *}$ Kyu-Ri Park ${ }^{3, *}$, Young-Kwon Kim ${ }^{4, *}$, \\ Jungho Kim ${ }^{5, ;}, *$ and Young-Bin $\mathrm{Yu}^{6, \dagger ; *}$ \\ ${ }^{I}$ Department of Laboratory Medicine, Yeouido ST. Mary's Hospital, The Catholic University, Seoul 07345, Korea \\ ${ }^{2}$ Department of Laboratory Medicine, Konyang University Hospital, Daejeon 33365, Korea \\ ${ }^{3}$ Korea Association of Health Promotion, Kyeryong-ro, Seo-gu, Daejeon 35264, Korea \\ ${ }^{4}$ Department of Health Sciences, The Graduate School of Konyang University, Daejeon 33365, Korea \\ ${ }^{5}$ Department of Clinical Laboratory Sciences, College of Health Sciences, \\ Catholic University of Pusan, Busan 46252, Korea \\ ${ }^{6}$ Department of Biomedical Laboratory Science, College of Medical Sciences, \\ Konyang University, Daejeon 33365, Korea
}

\begin{abstract}
Mobile phones used by healthcare workers are not only an indicator of the contamination of healthcare associated bacteria, but can also be another source of infection. The number and time of handwashing, mobile phone operation time and disinfection were highly relation with the bacterial contamination on the surface of mobile phone. Healthcare associated bacteria isolated from the mobile phone surface were $28 \mathrm{MRCoNS}$ (48.3\%), 14 S. aureus (24.2\%), $3 \mathrm{MRSA}$ (5.2\%), 5 A. baumannii (8.6\%), 3 MRAB (5.2\%), 3 Entrococcus spp. (5.1\%), 2 Pantoea spp. (3.4\%), 2 A. lowffii (3.4\%), 1 E. cloacae (1.7\%), 1 P. stutzeri (1.7\%), and P. mirabillis (1.7\%). For isolation according to department, 2 MRAB from the emergency room and 1 MRSA from intensive unit, the radiology team and the rehabilitation medical team, respectively were isolated. As a result of the relation of isolates from the department of patient contact (ER, RT, GW, CP, ICU, RMT), the bacterial isolation rate was $75 \%$ and the department of patient non-contact (MRT) was $10 \%$.
\end{abstract}

Key Words: Handwashing, Healthcare workers, Infection control, Mobile phone, Patient contact

\section{서 론}

최근의 의료 환경에서 휴대폰은 병원에서 근무하는 의 료종사자에게는 일상적인 연락 뿐만 아니라 의료정보의 전달 등 의료 행위의 수단으로 사용되는 필수적인 장비
이고 환자의 진료나 일상적인 업무를 할 때 의료진의 손 과 자주 접촉하게 된다(Kim et al., 2010). 인터넷과 빅 데이 터, 정보 공유 뿐 만 아니라, IT 휴대 기기들을 마치 장신 구처럼 몸에 착용할 수 있는(wearable device) 단계까지 오 게 됨에 따라 감염관리 업무에 있어서도 다양하게 반영 될 날이 멀지 않았다(Yoo, 2016). 병원 근무자들이 사용하

Received: November 22, 2021 / Revised: December 2, 2021 / Accepted: December 3, 2021

* Professor.

${ }^{\dagger}$ Corresponding author: Jungho Kim. Department of Clinical Laboratory Sciences, College of Health Sciences, Catholic University of Pusan, Busan 46252, Korea.

Tel: +82-10-6792-0073, Fax:+82-51-510-0568, e-mail: jutosa70@cup.ac.kr

${ }^{\dagger}$ Corresponding author: Young-Bin Yu. Department of Biomedical Laboratory Science, College of Medical Sciences, Konyang University, Daejeon 33365, Korea.

Tel: +82-10-4544-3126, Fax: +82-42-600-8435, e-mail: ybyoo@konyang.ac.kr

(C) The Korean Society for Biomedical Laboratory Sciences. All rights reserved.

(c) This is an Open Access article distributed under the terms of the Creative Commons Attribution Non-Commercial License (http://creativecommons.org/licenses/by-nc/3.0/) which permits unrestricted non-commercial use, distribution, and reproduction in any medium, provided the original work is properly cited. 
고 있는 휴대폰은 의료관련 감염균의 오염을 나타내는 하나의 지표일 뿐만 아니라 의료관련 감염균의 또 다른 감염원이 될 수 있다. 휴대폰의 사용 및 휴대는 일반적으 로 손이나 주머니, 가방 등의 휴대 환경을 통해 의료관련 감염균을 전파할 수 있다. 실제로 의료관련 감염균은 병 원 근무자들과 환자와의 직접적인 접촉으로 병원 근무자 들의 오염된 손을 통해 감염되기도 하지만 오염된 병원 환경이나 기구를 통해 병원 근무자들의 손이 오염되어 감염되기도 한다(Otter et al., 2011). 더욱이 최근에는 여러 계열의 항균제에 내성을 가지는 카바페넴 내성 장내 세 균(carbapenem-resistant Enterobacteriaceae, CRE), 다제내성 녹농균(multidrug-resistant Pseudomonas aeruginosa), 다제 내성 아시네토박터(multidrug-resistant Acinetobacter), 메티 실린 내성 황색포도알균(methicillin-resistant Staphylococcus aureus, MRSA), 반코마이신 내성 황색포도알균(vancomycin -resistant Staphylcoccus aureus, VRSA), 반코마이신 내성 장 알균(vancomycin-resistant Enterococi, VRE) 등의 다제 내성 균(multidrug-resistant organisms)에 의한 의료관련 감염이 늘어나고 있다(CDC, 2013)는 점에서 의료관련 감염균의 또 다른 감염원이 될 수 있는 휴대폰에 대한 연구와 관 리가 필요하다. 즉, 병원 내 의료관련 감염균으로 자주 분리되는 세균이나 내성균이 원내 환경을 오염시키는 경 우 간접적인 감염이 가능하다는 점에서 병원 내 환경에 서 의료관련 감염 세균의 오염을 파악하고 이를 줄이려 는 노력이 필요하다(Siegel et al., 2007). 본 연구에서는 의 료종사자들의 휴대폰 표면에 의료관련 감염균의 오염을 확인한 후 휴대폰 표면의 의료관련 감염균의 오염에 영 향을 미치는 요인을 분석하고 나아가 손 씻기가 휴대폰 표면의 의료관련 감염균의 오염에 영향을 미치는 중요한 원인 중 하나 일 것 이라는 가설을 세우고 손 씻기에 영 향을 미치는 요인을 함께 분석함으로써 감염관리 대책을 세우는데 필요한 기본 자료를 제공하고자 하였다.

\section{재료 및 방법}

\section{재료}

서울의 한 대학병원에서 환자 비접촉 부서인 의무기록 팀과 접촉 부서인 응급실, 영상의학팀, 일반 병동, 진단검 사의학팀, 중환자실, 재활의학팀, 간호보조 부서에서 각 부서 당 10 명의 근무자들과 그들의 휴대폰 80 개를 대상 으로 설문조사와 세균 배양을 하였다.

\section{의료관련 감염균의 선정}

본 연구에서는 질병관리청에서 표본감시(surveillance) 대상 법정감염병으로 등재된 6종의 의료관련 감염균과 감염관리학회에서 잠재적 병원성 세균으로 분리하고 있는 세균들을 휴대폰에서 분리하고자 아래와 같이 선정하였 다. 그람양성알균(Gram positive cocci, GPC): Staphylococcus aureus, methicillin-resistant $S$. aureus (MRSA), Enterococcus spp., vancomycin-resistant enterococci (VRE), methicillinresistant coagulase-negative Staphylococci (MRCoNS), Streptococcus group A, Streptococcus group B. 그람음성 막대균 (Gram negative bacilli): Acinetobacter baumanii, Pseudomonas aeruginosa, Enterobacteriaceae. 휴대폰 표면에서 검출된 coagulase-negative staphylococci (CoNS), Micrococcus spp., Bacillus spp., Diphtheroid, viridans Streptococci 등은 병원성 이 낮고 환경에 많이 분포하기 때문에 휴대폰 표면의 오 염 정도를 나타내는 의료관련 감염균에서 제외하였다.

\section{휴대전화에서 세균의 분리배양}

병원 내 각 부서 당 10 명에게 $\mathrm{IRB}$ 에서 승인된 연구계 획서를 설명한 후 설문지를 작성하는 동안 설문 대상자 휴대폰을 받아 생리식염수를 묻힌 소독된 면봉으로 근무 자들이 자주 사용하는 휴대폰의 액정과 자판 그리고 휴 대폰 뒷면을 도말하여 세균 배양 검사를 위해 혈액우무 배지(blood agar plate, BAP)와 MacConkey agar를 사용하였 고, $\mathrm{BAP}$ 와 MacConkey agar는 $37^{\circ} \mathrm{C}, 5 \% \mathrm{CO}_{2}$ 배양기에서 24 48시간 동안 배양하였다.

\section{분리된 세균의 동정}

$\mathrm{BAP}$ 에서 전체 세균 집락수를 측정하고, $\mathrm{BAP}$ 와 $\mathrm{Mac}-$ Conkey agar에서 Staphylococcus spp., Streptococcus spp., Micrococcus spp., Bacillus spp., 그람음성 막대균, Diphtheroid 등의 균종으로 의심되는 집락을 1 2개를 선택하여 그람 염색하고 동정을 실시하였다.

BAP에서 Staphylococcus spp.,가 의심되는 집락은 2개씩 선택하여 catalase, PS latex 검사로 S. aureus와 coagulasenegative staphylococci $(\mathrm{CoNS})$ 를 감별하였고, 메티실린 내성 검사는 cefoxitin 디스크 확산법으로 시행하였다.

Micrococcus spp.나 Diphtheroids가 의심되는 집락은 그 람염색 소견을 통해 잠정 동정하였다. 동정된 균주는 Microscan (Siemens, West Sacramento, USA)과 Vitek 2 (Biomerieux, Durham, USA)를 이용하여 최종 동정하였다. 
Table 1. Isolates from mobile phones of health care workers in a university hospital

\begin{tabular}{|c|c|c|c|c|c|c|c|c|c|}
\hline Classification & $\mathrm{GW}^{\mathrm{d}}$ & $\mathrm{ICU}^{\mathrm{e}}$ & $\mathrm{ER}^{\mathrm{f}}$ & $\mathrm{CP}^{\mathrm{g}}$ & $\mathrm{RT}^{\mathrm{h}}$ & $\mathrm{RMT}^{\mathrm{i}}$ & MRT $^{\mathrm{j}}$ & $\mathrm{AN}^{\mathrm{k}}$ & Total $(\%)$ \\
\hline $\mathrm{MRCoNS}^{\mathrm{a}}$ & 4 & 6 & 2 & 6 & 1 & 2 & 1 & 6 & $28(48.3)$ \\
\hline Staphylococcus aureus & 2 & 2 & 1 & 0 & 1 & 3 & 0 & 2 & $11(19.0)$ \\
\hline $\mathrm{MRSA}^{\mathrm{b}}$ & 0 & 1 & 0 & 0 & 1 & 1 & 0 & 0 & $3(5.2)$ \\
\hline Acinetobacter baumannii & 0 & 0 & 0 & 1 & 1 & 1 & 0 & 0 & $3(5.2)$ \\
\hline $\mathrm{MRAB}^{\mathrm{c}}$ & 0 & 0 & 2 & 0 & 0 & 0 & 0 & 0 & $2(3.4)$ \\
\hline Enterococcus faecium & 0 & 0 & 0 & 1 & 0 & 0 & 0 & 1 & $2(3.4)$ \\
\hline Pantoea sp. & 1 & 0 & 0 & 1 & 0 & 0 & 0 & 0 & $2(3.4)$ \\
\hline Acinetobacter lowffii & 0 & 0 & 0 & 0 & 0 & 0 & 0 & 2 & $2(3.4)$ \\
\hline Enterococcus durans & 0 & 0 & 0 & 0 & 0 & 1 & 0 & 0 & $1(1.7)$ \\
\hline Enterobacter cloacae & 1 & 0 & 0 & 0 & 0 & 0 & 0 & 0 & $1(1.7)$ \\
\hline Pseudomonas stutzeri & 0 & 0 & 0 & 0 & 0 & 1 & 0 & 0 & $1(1.7)$ \\
\hline Streptococcus agalactiae & 0 & 0 & 0 & 0 & 0 & 1 & 0 & 0 & $1(1.7)$ \\
\hline Proteus mirabillis & 0 & 0 & 0 & 0 & 0 & 0 & 0 & 1 & $1(1.7)$ \\
\hline $\begin{array}{c}\text { Total } \\
(\%)\end{array}$ & $\begin{array}{c}8 \\
(13.8)\end{array}$ & $\begin{array}{c}9 \\
(15.5)\end{array}$ & $\begin{array}{c}5 \\
(8.6)\end{array}$ & $\begin{array}{c}9 \\
(15.5)\end{array}$ & $\begin{array}{c}4 \\
(6.9)\end{array}$ & $\begin{array}{c}10 \\
(17.2)\end{array}$ & $\begin{array}{c}1 \\
(1.7)\end{array}$ & $\begin{array}{c}12 \\
(20.7)\end{array}$ & $\begin{array}{c}58 \\
(100)\end{array}$ \\
\hline
\end{tabular}

${ }^{\mathrm{a}}$ MRCoNS, methicillin-resistant coagulase-negative staphylococci; ${ }^{\mathrm{b}} \mathrm{MRSA}$, methicillin-resistant S. aureus; ${ }^{\mathrm{c}}$ MRAB, multidrug-resistant Acinetobacter baumanii; ${ }^{\mathrm{d}} \mathrm{GW}$, General word; ${ }^{\mathrm{e}} \mathrm{ICU}$, Intencive care unit; ${ }_{\mathrm{f}}^{\mathrm{E}} \mathrm{E}$, Emergency room; ${ }^{\mathrm{g}} \mathrm{CP}$, Clinical pathology; ${ }^{\mathrm{h}} \mathrm{RT}$, Radiation team; ${ }^{i}$ RMT, Rehabilitation medicine team; ${ }^{j}$ MRT, Medical record team; ${ }^{k}$ AN, Assistant nurse

\section{결 과}

\section{휴대폰으로부터 의료관련 감염균의 분리}

병원 근무자 80 명의 휴대폰 세균 배양 결과 MRCoNS는 28 주(48.3\%), S. aureus는 14주(24.2\%)가 분리되었으며, 이 중 methicillin-resistant $S$. aureus (MRSA)는 3주(5.2\%)가 분리 되었다. 대표적인 원내 감염균인 Acinetobacter baumannii는 5 주 $(8.6 \%)$ 가 분리되었으며 $\mathrm{MRAB}$ 의 분리율은 2 주(3.4\%) 이었다. Enterococcus spp. 3주(5.1\%), 그 외 그람음성 막대 균은 Pantoea spp. 2주(3.4\%), Acinetobacter lowffii 2주(3.4\%), Enterococcus cloacae, Pseudomonas stutzeri, Proteus mirabillis 1 주씩 분리되었다. MRCoNS는 부서별로 $\mathrm{ICU}, 6$ 주, $\mathrm{AN}, 6$ 주, $\mathrm{CP}, 6$ 주, $\mathrm{GW}, 4$ 주, ER, 2주, RMT, 2주, RT, 1주, MRT 1주가 분리되었고 Staphylococcus aureus는 부서별로 RMT, 4주, $\mathrm{ICU}, 3$ 주, ER, 3 주, RT, 2주, $\mathrm{GW}, 2$ 주 $\mathrm{AN}, 2$ 주가 분리되었다. Acinetobacter baumannii는 부서별로 $\mathrm{CP}, 1$ 주 RT, 1주, RMT, 1 주가 분리되었다. Enterococcus spp.는 부서별로 $\mathrm{CP}, 1$ 주, RMT, 1주, AN, 1주가 분리되었고 Pantoea spp.는 부서별로 $\mathrm{GW}, 1$ 주, $\mathrm{CP}, 1$ 주가 분리되었으며 Acinetobacter lowffii는 $\mathrm{AN}$ 에서 2주가, Enterococcus cloacae, Pseudomonas stutzeri, Proteus mirabillis 각각 $\mathrm{GW}, \mathrm{RMT}, \mathrm{AN} 1$ 주씩 분리되었다. 부서별로는 다른 부서에서는 분리되지 않은 multidrug-
Table 2. The relation of between times of hand washing and number of bacterial isolates on mobile phone surface in each department (\%)

\begin{tabular}{lcc}
\hline \hline Department & $\begin{array}{c}\text { Times of hand } \\
\text { washing }\end{array}$ & $\begin{array}{c}\text { No. of isolates/mobile } \\
\text { phone (\%) }\end{array}$ \\
\hline $\mathrm{ICU}^{* *, \mathrm{a}}$ & 23.8 & $9 / 10(90)$ \\
$\mathrm{ER}^{* *, \mathrm{~b}}$ & 22.5 & $5 / 10(50)$ \\
$\mathrm{RMT}^{* *, \mathrm{c}}$ & 21.0 & $10 / 10(100)$ \\
$\mathrm{RT}^{* *, \mathrm{~d}}$ & 20.3 & $4 / 10(40)$ \\
$\mathrm{CP}^{* *, \mathrm{e}}$ & 17.8 & $9 / 10(90)$ \\
$\mathrm{GW}^{* *, \mathrm{f}}$ & 16.3 & $8 / 10(80)$ \\
$\mathrm{AN}^{* *, \mathrm{~g}}$ & 8.9 & $10 / 10(100)$ \\
$\mathrm{MRT}^{*}, \mathrm{~h}$ & 7.7 & $1 / 10(10)$ \\
\hline
\end{tabular}

*Non patient contact Group, ${ }^{* *}$ Patient contact Group

${ }^{\mathrm{a}} \mathrm{ICU}$, Intencive care unit; ${ }^{\mathrm{b}} \mathrm{ER}$, Emergency room; ${ }^{\mathrm{c}} \mathrm{RMT}$, Rehabilitation medicine team; ${ }^{\mathrm{d}} \mathrm{RT}$, Radiation team; ${ }^{\mathrm{e}} \mathrm{CP}$, Clinical pathology; ${ }^{\mathrm{f}} \mathrm{GW}$, General word; ${ }^{\mathrm{g}} \mathrm{AN}$, Assistant nurse; ${ }^{\mathrm{h}}$ MRT, Medical record team

resistant Acinetobacter baumanii (MRAB)가 ER에서만 2주가 분리되었으며, MRSA 균주는 ICU과 RT, RMT에서만 1주 씩 분리되었다(Table 1). 


\section{손 씻기와 휴대폰 오염의 관계}

각 부서별 10 명씩 총 80 명을 대상으로 손 씻기 횟수와 휴대폰 표면에서 분리된 세균을 비교한 결과, 손 씻기 횟 수 평균과 휴대폰 1 대당 분리된 세균 수의 평균은 중환자 실 23.8회, 0.9 주, 응급실 22.5회, 0.5 주, 재활의학팀 21.0 회, 1.0 주, 영상의학팀 20.3회, 0.4주, 일반 병동 16.3회, 0.8 주,

Table 3. The relation of between times of hand washing and the number of bacterial isolates on mobile phone (\%)

\begin{tabular}{|c|c|c|}
\hline Department & $\begin{array}{l}\text { Hand washing } \\
\text { time ( } \mathrm{sec})\end{array}$ & $\begin{array}{c}\text { No. of isolates/mobile } \\
\text { phone }(\%)\end{array}$ \\
\hline \multirow{4}{*}{$\mathrm{ICU}^{\mathrm{a}}$} & $6 \sim 10$ & $1 / 2(50)$ \\
\hline & $11 \sim 20$ & $3 / 4(75)$ \\
\hline & $21 \sim 30$ & 1/1 (100) \\
\hline & $>31$ & $3 / 4(75)$ \\
\hline \multirow{3}{*}{$\mathrm{ER}^{\mathrm{b}}$} & $11 \sim 20$ & $1 / 5(20)$ \\
\hline & $21 \sim 30$ & $2 / 3(67)$ \\
\hline & $>31$ & $2 / 2(100)$ \\
\hline \multirow{4}{*}{$\mathrm{RMT}^{\mathrm{c}}$} & $6 \sim 10$ & $2 / 2(100)$ \\
\hline & $11 \sim 20$ & $3 / 5(60)$ \\
\hline & $21 \sim 30$ & $3 / 3(100)$ \\
\hline & $>31$ & $0 / 2(0)$ \\
\hline \multirow{4}{*}{$\mathrm{RT}^{\mathrm{d}}$} & $6 \sim 10$ & $0 / 3(0)$ \\
\hline & $11 \sim 20$ & $2 / 2(100)$ \\
\hline & $21 \sim 30$ & 1/3 (33) \\
\hline & $>31$ & $1 / 2(50)$ \\
\hline \multirow{3}{*}{$\mathrm{CP}^{\mathrm{e}}$} & $6 \sim 10$ & $1 / 1(100)$ \\
\hline & $11 \sim 20$ & $6 / 6(100)$ \\
\hline & $21 \sim 30$ & $2 / 3(67)$ \\
\hline \multirow{4}{*}{$\mathrm{GW}^{\mathrm{f}}$} & $6 \sim 10$ & $3 / 3(100)$ \\
\hline & $11 \sim 20$ & $5 / 5(100)$ \\
\hline & $21 \sim 30$ & $0 / 1(0)$ \\
\hline & $>31$ & $0 / 1(0)$ \\
\hline \multirow{4}{*}{$\mathrm{AN}^{\mathrm{g}}$} & $<5$ & $1 / 1(100)$ \\
\hline & $6 \sim 10$ & $7 / 7$ (100) \\
\hline & $11 \sim 20$ & $1 / 2(50)$ \\
\hline & $>31$ & $0 / 1(0)$ \\
\hline \multirow{3}{*}{$\mathrm{MRT}^{\mathrm{h}}$} & $<5$ & $0 / 2(0)$ \\
\hline & $6 \sim 10$ & $0 / 7(0)$ \\
\hline & $11 \sim 20$ & 1/1 (100) \\
\hline
\end{tabular}

${ }^{\mathrm{a}} \mathrm{ICU}$, Intencive care unit; ${ }^{\mathrm{b}} \mathrm{ER}$, Emergency room; ${ }^{\mathrm{c}} \mathrm{RMT}$, Rehabilitation medicine team; ${ }^{\mathrm{d}} \mathrm{RT}$, Radiation team; ${ }^{\mathrm{e}} \mathrm{CP}$, Clinical pathology; ${ }^{\mathrm{f}} \mathrm{GW}$, General word; ${ }^{\mathrm{g}}$ AN, Assistant nurse; ${ }^{\text {h}}$ MRT, Medical record team
진단검사의학팀 17.8 회, 0.9 주, 간호보조 부서 8.9 회 1.2 주, 의무기록팀 7.7회에 0.1주 순 이었다(Table 2).

손 씻기와 휴대폰 표면에서 분리된 세균 수의 관계를 비교하기 위해 손 씻기 횟수 구간을 6 10회, 11 20회, 21 30회, 31회 이상으로 나누어 휴대폰 표면에서 분리된 세균 수를 분석하였다. 8 개 부서 중에서 응급실, 영상의학

Table 4. Relation of handwashing time and number of bacterial isolates on mobile phone (\%)

\begin{tabular}{|c|c|c|}
\hline Department & $\begin{array}{c}\text { Handwashing time } \\
(\mathrm{sec})\end{array}$ & $\begin{array}{c}\text { No. of isolates/mobile } \\
\text { phone }\end{array}$ \\
\hline \multirow{5}{*}{$\mathrm{ICU}^{\mathrm{a}}$} & 5 & $0 / 1(0)$ \\
\hline & 15.5 & $3 / 4(75)$ \\
\hline & 25.5 & $1 / 2(50)$ \\
\hline & 35.5 & 1/1 (100) \\
\hline & 45.5 & $3 / 3(100)$ \\
\hline \multirow{5}{*}{$\mathrm{ER}^{\mathrm{b}}$} & 5 & $0 / 2(0)$ \\
\hline & 15.5 & $2 / 4(50)$ \\
\hline & 25.5 & $2 / 2(100)$ \\
\hline & 35.5 & $0 / 1(0)$ \\
\hline & 45.5 & 1/1 (100) \\
\hline \multirow{3}{*}{$\mathrm{RMT}^{\mathrm{c}}$} & 5 & $3 / 4(75)$ \\
\hline & 15.5 & $4 / 4(100)$ \\
\hline & 35.5 & $0 / 3(0)$ \\
\hline \multirow{3}{*}{$\mathrm{RT}^{\mathrm{d}}$} & 15.5 & $3 / 8(35)$ \\
\hline & 25.5 & $1 / 1(100)$ \\
\hline & 45.5 & $0 / 1(0)$ \\
\hline \multirow{3}{*}{$\mathrm{CP}^{\mathrm{e}}$} & 5 & $1 / 2(50)$ \\
\hline & 15.5 & $7 / 7(100)$ \\
\hline & 25.5 & 1/9 (11) \\
\hline \multirow{3}{*}{$\mathrm{GW}^{\mathrm{f}}$} & 15.5 & $4 / 4(100)$ \\
\hline & 25.5 & $4 / 5(80)$ \\
\hline & 35.5 & $0 / 1(0)$ \\
\hline \multirow{3}{*}{$\mathrm{AN}^{\mathrm{g}}$} & $<5$ & $0 / 1(0)$ \\
\hline & 15.5 & $6 / 6(100)$ \\
\hline & 25.5 & $3 / 3(100)$ \\
\hline \multirow{3}{*}{$\mathrm{MRT}^{\mathrm{h}}$} & $<5$ & $0 / 3(0)$ \\
\hline & 15.5 & $1 / 6(17)$ \\
\hline & 35.5 & $0 / 1(0)$ \\
\hline
\end{tabular}

The average of time of hand washing in one-time (sec) is used by the average of the medians of interval and all of measured values are rounded to the one decimals

${ }^{\mathrm{a}}$ ICU, Intencive care unit; ${ }^{\mathrm{b}} \mathrm{ER}$, Emergency room; ${ }^{\mathrm{c}} \mathrm{RMT}$, Rehabilitation medicine team; ${ }^{\mathrm{d}} \mathrm{RT}$, Radiation team; ${ }^{\mathrm{e}} \mathrm{CP}$, Clinical pathology; ${ }^{\mathrm{f}} \mathrm{GW}$, General word; ${ }^{\mathrm{g}} \mathrm{AN}$, Assistant nurse; ${ }^{\mathrm{h}}$ MRT, Medical record team 
팀, 의무기록팀에서는 세균 수가 적게 검출되어 손 씻기 구간별 회수와 휴대폰 표면에서 분리된 세균 수의 관계 가 나타나지 않았으나 일반 병동, 진단검사의학팀, 중환자 실, 재활의학팀을 대상으로 손 씻기 횟수 구간을 6 10회, 11 20회, 21 30회, 31회 이상으로 나누어 손 씻기 횟수와 휴대폰 표면의 세균 오염을 비교한 결과 21 30회 이상 손을 씻는 경우부터는 휴대폰 1개당 분리된 세균 수의 평균은 감소하였다(Table 3).

손 씻기 1 회당 시간과 휴대폰 표면에서 분리된 세균 수의 관계를 비교하기 위해 손 씻는 1 회당 시간을 10 초 이하, 10 20초, 21 30초, 30 40초, 40초 이상으로 나누어 휴대폰 표면에서 분리된 세균 수를 분석하였다.

8 개부서의 중에서 응급실, 영상의학팀, 의무기록팀에서 는 휴대폰 표면에서 분리된 세균 수가 적게 검출되어 손 씻기 1 회당 시간과 휴대폰 표면에서 분리된 세균 수의 관계가 나타나지 않았으나 일반 병동, 진단검사의학팀, 중 환자실, 재활의학팀을 대상으로 손 씻기 1 회당 시간을 보 면 손 씻는 시간 평균이 25.5 초 이상인 경우 휴대폰 1 개 당 세균 수의 평균은 감소하였다(Table 4).

\section{휴대폰 조작 시간과 휴대폰 오염의 관계}

휴대폰 표면의 세균 오염과 손 씻기 정도가 유사한 부
서들에 대해서 휴대폰 조작 시간과 휴대폰의 표면 세균 의 관계를 조사한 결과 의무기록팀의 손 씻기 횟수 평균 은 7.7회, 휴대폰 조작 시간은 27.4분, 휴대폰 1개당 세 균 수의 평균은 0.1 주이었다. 손 씻기 횟수 평균이 각각 22.5 회, 20.3회, 휴대폰 1 개당 세균 수의 평균이 0.5 주, 0.4 주로 유사한 응급실과 영상의학팀의 휴대폰 조작 시간 은 각각 19.3 회, 28.5 회이었다. 손 씻기 횟수 평균이 각각 16.3 회, 17.8 회, 휴대폰 1 개당 세균 수의 평균이 0.8 주, 0.9 주 로 유사한 일반 병동과 진단검사의학팀의 휴대폰 조작 시간은 각각 12.3 회, 26.5 회이었다. 손 씻기 횟수 평균이 각각 23.8회, 21.0회, 휴대폰 1 개당 세균의 종류 개수 평균 이 0.9 주, 1.0 주로 유사한 중환자실과 재활의학팀의 휴대 폰 조작 시간은 각각 8.1 회, 29.4회이었다. 이러한 결과 휴 대폰 조작 시간과 휴대폰 표면의 세균 수와는 연관성이 나타나지 않았다(Table 5).

\section{부서별 특성과 휴대폰 표면 오염의 관계}

부서별 특성과 휴대폰 표면의 세균 분리를 비교한 결 과, 환자 비접촉 부서인 의무기록팀은 손 씻기 횟수 평 균이 7.7 회이었고 휴대폰 1 개당 세균의 종류 개수 평균은 0.1 주이었다. 환자 접촉 부서인 응급실, 영상의학팀, 일반 병동, 진단검사의학팀, 중환자실, 재활의학팀 전체의 손

Table 5. The relation of mobile phone using time and isolates on mobile phone in each department (\%)

\begin{tabular}{lccc}
\hline \hline \multicolumn{1}{c}{ Department } & Mobile phone using time $(\mathrm{min})$ & Handwashing time $(\mathrm{sec})$ & No. of isolates/mobile phone \\
\hline $\mathrm{AN}^{\mathrm{a}}$ & 29.5 & 9.9 & $10 / 10(100)$ \\
$\mathrm{RMT}^{\mathrm{b}}$ & 29.4 & 21.0 & $10 / 10(100)$ \\
$\mathrm{RT}^{\mathrm{c}}$ & 28.5 & 20.3 & $4 / 10(40)$ \\
$\mathrm{MRT}^{\mathrm{d}}$ & 27.4 & 7.7 & $1 / 10(10)$ \\
$\mathrm{CP}^{\mathrm{e}}$ & 26.5 & 17.8 & $9 / 10(90)$ \\
$\mathrm{ER}^{\mathrm{f}}$ & 19.3 & 22.5 & $5 / 10(50)$ \\
$\mathrm{GW}^{\mathrm{g}}$ & 12.3 & 16.3 & $8 / 10(80)$ \\
$\mathrm{ICU}^{\mathrm{h}}$ & 8.1 & 23.8 & $9 / 10(90)$ \\
\hline
\end{tabular}

${ }^{\mathrm{a}} \mathrm{AN}$, Assistant nurse; ${ }^{\mathrm{b}} \mathrm{RMT}$, Rehabilitation medicine team; ${ }^{\mathrm{c}} \mathrm{RT}$, Radiation team; ${ }^{\mathrm{d}}$ MRT, Medical record team; ${ }^{\mathrm{e}} \mathrm{CP}, \mathrm{Clinical}$ pathology;

${ }^{\mathrm{f}}$ ER, Emergency room; ${ }^{\mathrm{g}} \mathrm{GW}$, General word; ${ }^{\mathrm{h}} \mathrm{ICU}$, Intencive care unit

Table 6. Relation of isolates from department of patient contact and patient non-contact on mobile phone (\%)

\begin{tabular}{lccc}
\hline \hline \multicolumn{1}{c}{ Classification } & Department & Times of hand washing & No. of isolates / mobile phone \\
\hline Patient contact $(\mathrm{N}=60)$ & $\mathrm{ER}^{\mathrm{a}}, \mathrm{RT}^{\mathrm{b}}, \mathrm{GW}^{\mathrm{c}}, \mathrm{CP}^{\mathrm{d}}, \mathrm{ICU}^{\mathrm{e}}, \mathrm{RMT}^{\mathrm{f}}$ & 20.3 & $45 / 60(75)$ \\
Non patient contact $(\mathrm{N}=10)$ & $\mathrm{MRT}^{\mathrm{g}}$ & 7.7 & $1 / 10(10)$ \\
\hline
\end{tabular}

${ }^{\mathrm{a}}$ ER, Emergency room; ${ }^{\mathrm{b}} \mathrm{RT}$, Radiation team; ${ }^{\mathrm{c}} \mathrm{GW}$, General word; ${ }^{\mathrm{d}} \mathrm{CP}$, Clinical pathology; ${ }^{\mathrm{e}} \mathrm{ICU}$, Intencive care unit; ${ }^{\mathrm{f}}$ RMT, Rehabilitation medicine team; ${ }^{\mathrm{g}}$ MRT, Medical record team 
씻기 횟수 평균은 20.3회이었으며, 휴대폰 1개당 세균 수 의 평균은 0.75 주이었다. 단, 간호보조 부서는 부서와 부 서를 옮겨 다니고 여러 부서에서 일하므로 부서별 특성 을 대표한다고 볼 수 없어 부서와 부서 군 분류에서 제 외하였다.

환자접촉 부서에서 응급실과 영상의학팀은 손 씻기 횟 수가 각각 22.5회, 20.3회, 휴대폰 1 개당 세균 수의 평균은 0.5 주, 0.4 주로 유사하였다. 일반 병동과 진단검사의학팀은 손 씻기 횟수가 각각 16.3 회, 17.8회, 휴대폰 1 개당 세균 수의 평균은 0.8 주, 0.9 주로 유사하였다. 중환자실과 재활 의학팀은 손 씻기 횟수가 각각 23.8회, 21.0 회, 휴대폰 1 개 당 세균 수의 평균은 0.9 주, 1.0 주로 유사하였다. 부서별 특성과 휴대폰 표면에서 분리된 세균의 수를 비교한 결 과 휴대폰 표면의 세균 수는 부서의 환자접촉 여부와 대 상 환자의 차이 등 해당 부서와 관련이 있었다(Table 6).

\section{고 찰}

최근의 의료 환경에서 의료종사자들이 휴대폰을 일상 적인 연락 뿐 만 아니라 의료정보의 전달 등 필수적인 의료 행위의 수단으로 사용함에 따라 휴대폰은 의료관련 감염균의 오염을 나타내는 하나의 지표일 뿐만 아니라 의료관련 감염균의 또 다른 감염원이 될 수 있다. 따라서 휴대폰 표면에서 세균을 분리 동정하고 의료관련 감염균 에 대한 영향을 분석함으로서 보다 효율적인 감염관리 대책을 세우는데 기본 연구자료로 활용하고자 하였다.

본 연구의 실험 결과 병원 근무자 80 명의 휴대전화 세 균 배양 결과 MRCoNS는 28주(48.3\%), S. aureus는 14주 (24.2\%), MRSA는 3주(5.2\%), A. baumannii는 5주(8.6\%), $\mathrm{MRAB}$ 는 2주(3.4\%), Enterococcus spp. 3주(5.1\%), Pantoea spp. 2주(3.4\%) E. cloacae, P. stutzeri, P. mirabillis, A. owffii 1 주씩 분리되었다. 부서별로는 다른 부서에서는 분리되 지 않은 multidrug-resistant Acinetobacter baumanii (MRAB) 가 응급실에서만 2주가 분리되었으며 MRSA 균주는 중 환자실과 영상의학팀, 재활의학팀에서만 1 주씩 분리되었 다. 의료진의 휴대전화에서 분리된 의료관련 감염 병원 균에서는 인턴과 레지던트 101 명의 휴대폰을 대상으로 S. aureus는 13주(12.9\%), VRE는 1주(1.0\%), MRSA는 4주 (4.0\%), MRCoNs는 38주(37.6\%)였고 그람음성 막대균은 분 리되지 않았다(Kim et al., 2010). 본 연구의 결과와 선행 연 구 결과가 약간의 차이를 보이는 것은 연구 대상과 연구 시점, 그리고 검사 방법이 다르기 때문이라고 생각된다.
부서별 손 씻기 횟수 평균과 휴대폰 표면의 세균을 조 사한 결과 휴대폰 표면의 세균이 손 씻기 횟수와 관계가 없는 것으로 나타났으나 이러한 원인은 손 씻기 횟수와 휴대폰 표면의 세균은 부서별 업무 특성의 영향을 받아 나타난 것으로 볼 수 있었다.

병동보다 중환자실에서 의료진의 손 위생 수행률이 높 지만(Chun et al., 2014) 부서의 특성으로 인해 중환자실은 일반 병동에 비해서 의료관련 감염균의 오염이 높다는 보고가 있다(Lee et al., 2014). 이러한 부서별 특성의 영향 을 제거하기 위하여 손 씻기 횟수 평균과 휴대폰 표면의 세균이 유사한 부서 군을 대상으로 손 씻기 횟수와 휴대 폰 표면의 세균과의 관계를 비교하였다.

손 씻기 횟수와 휴대폰 표면의 세균 오염 관계를 명확 히 보여준 일반 병동, 진단검사의학팀, 중환자실, 재활의 학팀을 대상으로 조사한 결과 손 씻기 횟수가 많을수록 휴대폰 표면의 세균은 감소하였다. 또한, 손 씻기 1 회당 시간과 휴대폰 표면의 세균에 대해서도 손 씻기 1회당 시 간 평균 구간(초)을 2 개 구간(5 15.5초, $25.5 \sim 45.5$ 초)으로 나누어 조사한 결과 손 씻기 1 회당 시간이 길수록 휴대 폰 표면의 세균 검출 수가 감소하였다. 15초 미만(Ojajarvi, 1981), 15초 간(Sprunt et al., 1973), 50 60초 정도(Steere and Mallison, 1975) 손을 씻을 경우 일과성 미생물을 감소시킬 수 있다고 주장하였으나 본 연구에 의하면 평균 25초 이 상인 경우 휴대폰 표면에서 세균의 수가 감소하였다. 손 씻기를 횟수와 1 회당 시간(sec)으로 측정하였는데, 손 씻 기 횟수와 1 회당 시간의 관계를 조사한 결과 손 씻기 횟 수가 많아질수록 손 씻기 1회당 시간도 길었다. 이러한 조사 결과는 손 씻기 횟수와 손 씻기 1 회당 시간과는 관 련성이 없다는 연구 결과와는 달리 손 씻기 횟수가 많을 수록 손 씻기 1 회당 시간도 길어졌다는 연구 결과와 일 치하였다(Hur et al., 2010). 이러한 결과에 의하면 손 씻기 는 휴대폰 표면의 세균을 결정하는 주된 원인 중 하나라 고 판단된다. 병원 근무자들 중에는 매일 퇴근 직전에 휴 대폰을 소독하는 근무자들이 있다. 퇴근 직전 휴대폰 소 독 행위와 휴대폰 표면의 세균 수와의 관계를 조사한 선 행 연구를 찾을 수는 없었으나 이러한 휴대폰 소독 행위 는 병원 내 근무 중 휴대폰 표면의 세균에 영향을 미칠 수 있어 휴대폰 소독과 휴대폰 표면의 세균과의 관계를 비교한 결과 휴대폰 소독 점수가 가장 높은 25점일 때 휴대폰 표면의 세균 분리가 가장 많았다.

환자접촉 부서들에 대해 손 씻기 횟수 평균이 유사한 부서별로 휴대폰 표면에서 분리된 세균을 조사한 결과 
부서와 부서 군에 따라 세균 오염이 다르게 나타났다. 응급실의 휴대폰 1 개당 분리된 세균의 수 평균은 0.5 주 $(50 \%)$, 일반 병동의 휴대폰 1 개당 분리된 세균의 수 평균 은 0.8 주 $(80 \%)$, 중환자실 휴대폰 1 개당 분리된 세균 수의 평균은 0.9 주( $90 \%$ )이었다. 이러한 결과는 비강 내 MRSA 검출 기준으로 본 부서별 의료관련 감염균에 대한 선행 연구에 따르면 응급실의 MRSA 분리율이 $7.3 \%$ 로 가장 낮았고 일반 병동은 $12.4 \%$ 이었고, 중환자실은 $27.7 \%$ 로 가장 높았다는 결과와 일치하였다(Kim et al., 2007). 이러 한 결과에 의하면 병원 내 부서별 업무 특성에 따라 의 료관련 감염균의 휴대폰 오염에 영향을 미치는 주된 원 인 중 하나로 생각된다. 또한 본 연구에서 휴대폰 표면의 세균 오염을 줄이기 위해 손 씻기 시간보다는 손 씻기 횟수가 더 높게 나온 것은 손 씻는 시간의 중요성에 대 한 교육과 실천이 필요할 것으로 생각되며, 차기 실험에 서는 표본 수를 확대하고 휴대폰의 표면 배양과 동시에 병원 근무자의 손 배양을 동시에 실험한다면 보다 구체 적인 감염관리 대안을 도출할 수 있을 것으로 생각된다.

\section{ACKNOWLEDGEMENT}

None.

\section{CONFLICT OF INTEREST}

No potential conflict of interest relevant to this article was reported.

\section{REFERENCES}

CDC. CDC web sites on Antibiotic resistance threats in the United Stat es, 2013 (Updated on 2013).

Chun HK, Kim ML, Hwang JI. Hand Hygiene Promotion in a Hospital Setting through the WHO Multimodal Hand Hygiene Improvement Strategy. Korean J Nosocomial Infect Control. 2014. 19: 1-14.

Hur SY, Kwon HJ, Kim JS. A Study on Recognition and Performance of Medical Manpower about the Hand Washing. Journal of the Korea Data Analysis Society. 2010. 12: 1979-
1991.

Kim JS, Kwon OK, Song WK, et al. Isolation of HealthcareAssociated Pathogens from Cellular Phones Used by Medical Personnel. Korean J Nosocomial Infect Control. 2010. 15: 3640.

Kim OS, Yoon SW, Kang YJ, Kim YK, Lee NY, Lee JH, et al. Rate of Nasal Colonization of Methicillin-Resistant Staphylococcus aureus at Admission to a Medical Intensive Care Unit. Korean J Nosocomial Infect Control. 2007. 12: 42-49.

Lee YS, Kim YA, Song WK, et al. KONS AR Group. Recent Trends in Antimicrobial Resistance. in Intensive Care Units in Korea." Korean J Nosocomial Infect Control. 2014. 19: 29-36.

Ojajarvi J. The importance of soap selection for routine hygiene in hospital. Journal Hygine. 1981. 86: 275-283.

Otter JA, Yezli S, French GL. The role played by contaminated surface $\mathrm{s}$ in the transmission of nosocomial pathogens. Infect Control Hospital Epidemiol. 2011. 32: 687-699.

Siegel JD, Rhinehart E, Jackson M, Chiarello L. Healthcare Infection Control Practices Advisory Committee. Management of multidrug-resist ant organisms in health care settings. Am J Infect Control. 2007. 35: 165-193.

Sprunt K. Redman W. Leidy G. Antimicrobacterial effectiveness of routine handwashing. Pediatrics. 1973. 52: 264-271.

Steere AC, Mallison GF. Handwashing Practices for the Preven tion of Nosocomial Infections. Annals of Internal Medicine. 1975. 83: 683-690

Yoo JH. The Recent Trend and Perspective of Infection Control in the Republic of Korea. Korean J Nosocomial Infect Control 2016. 21: 1-8.

https://doi.org/10.15616/BSL.2021.27.4.310

Cite this article as: Choi MG, Kim $\mathrm{SH}$, Park KR, Kim YK, Kim J, Yu YB. Relation of Handwashing and Isolate of Bacteria from Mobile Phones of Healthcare Workers in a University Hospital. Biomedical Science Letters. 2021. 27: 310-316. 